\title{
Negoisasi Sebagai Upaya Alternative Penyelesaian Kredit Macet Di Bidang Perbankan Secara Win-Win Solution
}

\author{
Dede Suana Ependi ${ }^{1}$, Devi Siti Hamzah Marpaung ${ }^{2}$ \\ ${ }^{1,2,3}$ Fakultas Hukum, Universitas Singaperbangsa Karawang, Indonesia \\ Jalan HS Rongowaluyo, Telukjambe Timur, Karawang, Jawabarat 41361 \\ Correspondence email: dedesuanaaa23@gmail.com; devishm89@gmail.com
}

\begin{abstract}
Abstrak. Perbankan adalah salah satu sumber dana diantaranya dalam bentuk perkreditan bagi masyarakat. Perbankan dalam memberikan kreditnya akan sangat berhati-hati dan melalui analisis yang lebih mendalam. Namun dalam melakukan pemberian kredit tersebut sering kali kredit yang diberikan pada debitur tidak dapat kembali tepat pada waktunya. Kondisi ini dinamakan kredit macet. Tujuan dari penelitian ini adalah untuk mengetahui faktor apa saja yang menyebabkan terjadinya kredit macet di bidang perbankan dan bagaimana cara penyelesaiannya yang dilakukan secara non-litigasi. Metode yang digunakan dalam penelitian ini adalah metode yuridis-normatif, dalam penelitiannya dilakukan dengan cara studi kepustakaan buku-buku hukum, Peraturan Perundang-undangan, litelatur beserta referensi lainnya. Hasil penelitian ini menunjukan bahwa Faktor penyebab terjadinya kredit macet di bidang perbankan diantaranya adanya kegagalan yang menima usaha debitur, adanya itikad tidak baik dari debitur, ditemukannya pinjaman kredit tanpa sepengetahuan pihak keluarga yang dapat menyebabkan kurangnya rasa tanggung jawab, penyalahgunaan kredit oleh debitur dan adanya debitur debitur yang bekerja sebagai buruh, petani, nelayan sehingga keuangan mereka tidak bisa dijamin pada setiap saat, melainkan pada waktu tertentu saja. Adapun cara penyelesaian kredit macet melalui jalur non-litigasi yaitu secara negoisasi yang dapat dilakukan melalui tiga cara diantaranya penjadwalan kembali (Rescheduling), persyaratan kembali (Reconditioning), dan penataan kembali (Restructuring).
\end{abstract}

Kata Kunci : Negoisasi, Penyelesaian Kredit Macet, Perbankan

Abstract. Banking is one of the sources of funds, including in the form of credit for the community. Banks in providing credit will be very careful and will go through a more in-depth analysis. However, in providing credit, often the credit given to the debtor cannot be returned on time. This condition is called bad credit. The purpose of this study is to determine what factors cause bad credit in the banking sector and how to solve it in non-litigation ways. The method used in this research is the juridical-normative method, in which the research is carried out by means of literature study of law books, statutory regulations, literature and other references. The results of this study indicate that the factors causing the occurrence of bad credit in the banking sector include failure to accept the debtor's business, bad faith from the debtor, the discovery of credit loans without the knowledge of the family which can lead to a lack of responsibility, credit abuse by debtors and the presence of debtors. debtors who work as laborers, farmers, fishermen so that their finances cannot be guaranteed at all times, but only at certain times. As for the way to settle bad credit through non-litigation channels, namely by negotiation which can be done in three ways including rescheduling, reconditioning, and restructuring.

Keywords: Negotiation, Bad Credit Settlement, Banking

\section{PENDAHULUAN}

Dalam perekonomian suatu negara, perbankan merupakan lembaga keuangan yang memiliki nilai yang sangat penting bagi masyarakat. Lembaga perbankan sendiri berfungsi sebagai penghubung antara pihak yang memiliki dana yang lebih dengan pihak yang kesulitan dalam memiliki dana. Selain bergerak di bidang pelayanan jasa untuk melayani kebutuhan masyarakat, Lembaga keuangan perbankan juga bergerak dalam kegiatan perkreditan untuk melayani kebutuhan pembiayaan bagi semua aspek perekonomian. Sebagai lembaga keuangan, perbankan melakukan berbagai jenis transaksi. Transaksi perbankan yang utama adalah menghimpun dana (funding) dan menyalurkan dana (lending) selain itu memberikan jasa-jasa bank lainnya (sevices). ${ }^{1}$

Berdasarkan Pasal 3 Undang-undang Perbankan bahwa "fungsi utama perbankan Indonesia adalah sebagai penghimpun dan penyalur dana masyarakat". Menunjang implementasi pemerataan pertumbuhan ekonomi dan stabilitas dalam negeri ke arah peningkatan kesejahteraan masyarakat merupakan tujuan dibangunnya perbankan di Indonesia.

Selain itu, perbankan juga mempunyai peranan dalam kegiatan penyaluran kredit. Dalam proses pembangunan, Aspek perkreditan merupak aspek yang sangat penting bagi masyarakat. Oleh karena itu aspek perkreditan masih sangat menentukan pertumbuhan perekonomian secara garis besar terutama di dalam negeri, sebagaimana diatur pada Pasal 4 Undang-Undang Perbankan jo. Pasal 3 Undang-Undang Perbankan Syariah. ${ }^{2}$

\footnotetext{
${ }^{1}$ Trisadini P. Usanti dan Abd. Shomad, Hukum Perbankan, (Jakarta, PT. Fajar Interpratama, 2016), hlm. 1.

${ }^{2}$ Ibid. hlm. 9.
} 
Kredit adalah penyediaan uang atau tagihan yang dapat dipersamakan dengan itu, berdasarkan persetujuan atau kesepakatan pinjam meminjam antara bank dengan pihak lain yang mewajibkan pihak peminjam untuk melunasi utangnya setelah jangka waktu tertentu dengan pemberian bunga. ${ }^{3}$

Definisi di atas menunjukan bahwa kredit lahir menurut suatu "persetujuan atau kesepakatan" atau menggunakan perkataan lain menurut adanya perjanjian. Dalam KUH Perdata, perjanjian kredit antara bank dengan nasabahnya tidak diatur secara konkret, tetapi dapat dikatakan bahwa landasan hukum pemberian kredit selain Undang-Undang Perbankan, juga berlandaskan pada ketentuan terkait hukum perjanjian sebagaimana telah diatur pada kitab III KUH Perdata. ${ }^{4}$

Dalam Pasal 24 Undang-Undang Nomor 10 Tahun 1998 disebutkan bahwa "Bank umum tidak memberikan kredit tanpa jaminan kepada siapapun juga." Lalu dibuatkan lah dalam SK Dirut Bank Indonesia Nomor 23/69/Kep/Dir Tanggal 28 Februari 1991 tentang jaminan pemberian kredit yang dalam Pasal 1 ayat (1) disebutkan bahwa Bank tidak diperkenakan memberikan kredit kepada siapapun juga tanpa adanya jaminan. Dalam melakukan pemberian kredit kepada debitur diperlukan adanya jaminan yaitu jaminan kebendaan. ${ }^{5}$

Selain itu, Dalam bukunya yang berjudul Bank Politik, Prof. G.M. Verryn Styart mengemukakan bahwa pengertian bank adalah suatu badan yang bertujuan untuk memuaskan kebutuhan kredit, baik dengan alat-alat pembayarannya sendiri atau dengan uang yang diperolehnya dari orang lain, maupun dengan jalan mengedarkan alatalat penukar baru berupa uang digital. ${ }^{6}$

Bank dalam memberikan kredit kepada debitur harus mendapatkan perlindungan. Tanpa adanya perlindungan, bank akan mengalami kesulitan dalam menghindari akibat yang akan datang, salah satu nya akibat dari debitur yang tidak dapat memenuhi prestasinya. Agar debitur tidak wanprestasi maka debitur harus menyerahkan barang jaminannya sebagai bentuk perlindungan terhadap kreditur apabila nantinya debitur wanprestasi, kreditur dapat mengeksekusi barang jaminan tersebut. Tindakan yang dapat dilakukan oleh bank dalam rangka memberikan perlindungan terhadap kreditnya, maka dapat dibedakan menjadi 2 (dua), yaitu perlindungan preventif dan perlindungan refresif. Definisi dari perlindungan preventif yaitu perlindungan yang dapat dilakukan untuk mencegah terjadinya kredit macet. Sedangkan definisi dari perlindungan refresif yaitu perlindungan untuk menyelesaikan kreditkredit yang telah mengalami ketidaklancaran. Oleh karena itu perlindungan kredit pada dasarnya adalah untuk mengurangi resiko yang nantinya bisa saja terjadi. ${ }^{7}$

Mekanisme penyelesaian sengketa perbankan terutama dalam kasus kredit macet ini dapat dibedakan menjadi dua, yaitu secara jalur litigasi dan jalur non-litigasi. Jalur litigasi merupakan jalur penyelesaian sengketa melalui pengadilan melalui lembaga penegak hukum yang berwenang sesuai dengan peraturan perundang-undangan, sehingga membutuhkan waktu yang sangat lama dalam melakukan persidangan nantinya. Sedangkan jalur non-litigasi adalah mekanisme penyelesaian sengketa diluar pengadilan, seperti mediasi, negoisasi, arbitrase, konsiliasi, penyelesaian adat dan lain-lain. ${ }^{8}$

Salah satu dari metode alternative penyelesaian sengketa yaitu negoisasi. Negoisasi adalah suatu proses tawarmenawar atau cara yang dilakukan untuk mencapai kesepakatan antara pihak satu dengan pihak lain secara berinteraksi, komunikasi yang persuasive. Hal ini dimaksudkan untuk mencari jalan keluar dalam suatu masalah yang sedang terjadi. Negoisasi menjadi suatu metode alternative penyelesaian sengketa yang sangat sederhana, tepat dan menguntungkan kedua belah pihak (win-win solution). Karena sifatnya hemat waktu, biaya murah dan dijamin kerahasiaannya. ${ }^{9}$

\section{METODE}

\section{Pendekatan Penelitian}

Pendekatan masalah dalam penelitian ini menggunakan metode yuridis normatif, yaitu: pendekatan yang bertitik tolak dari ketentuan peraturan perundang-undangan dan diteliti dilapangan untuk memperoleh faktor

\footnotetext{
${ }^{3}$ Pasal 1 Angka 11 Undang-Undang Nomor 10 Tahun 1998 Tentang Perubahan Atas Undang-Undang Nomor 7 Tahun 1992 Tentang Perbankan.

${ }^{4}$ Djunyanto Thriyana, "Penyelesaian Kredit Bermasalah Dalam Praktek Perbankan Di Indonesia". Dialogia Iuridica. Vol, 11 No. 2 (2020): 94.

5 Sigit Sapto Nugroho dan Yuni Purwanti. Hukum Perbankan Mengenal Prudent Banking Principle, (Klaten, Lakesisha, 2020), hlm. 32 .

${ }^{6}$ Hermansyah. Hukum Perbankan Nasional Indonesia (Jakarta, Kencana, 2005), hlm. 6.

${ }^{7}$ Muhammad Kaddhani,"Penyelesaian Kredit Bermasalah Melalui Jalur Non-Litigasi Pada PT. Bank Rakyat Indonesia (Persero) Tbk Cabang Sinjai”, Skripsi Ilmu Hukum, Program Sarjana Ilmu Hukum, (Makassar: Universitas Alauddin Makassar, 2018), dipublikasikan, hlm. 5

8 Ana Afriana Amir, "Penyelesaian Kredit Macet Melalui Jalur Non-Litigasi Pada PT. Bank Pembangunan Daerah Sulawesi Selatan dan Barat”, Tesis Magister Ilmu Hukum, (Makassar, Unhas, 2020), hlm. 8.

${ }^{9}$ Frans Hendra Winata. Hukum Penyelesaian Sengketa. Edisi 2, (Jakarta, Kencana, 2012), hlm 15
} 
pendukung dan hambatannya. ${ }^{10}$ Pendekatan yuridis normatif ini merupakan pendekatan dengan berdasarkan normanorma atau peraturan perundang-undangan yang mengikat serta mempunyai konsekuensi hukum yang jelas. Melalui pendekatan yuridis normatif ini diharapkan dapat mengetahui tentang suatu perundang-undangan yang berlaku.

\section{Spesifikasi Penelitian}

Dalam memperoleh data serta informasi pada penelitian ini, maka penulis menggunakan metode deskriptif analisis, metode ini dilakukan dengan cara mendeskripsikan atau memberikan gambaran terkait objek yang akan diteliti melalui data-data yang sudah terkumpul.

\section{Jenis dan Sumber Data}

Data yang diambil dalam penelitian ini yaitu dengan menggunakan data sekunder, yaitu melakukan studi kepustakaan, mempelajari peraturan-peraturan perundang-undangan, serta literature lainnya.

\section{HASIL DAN PEMBAHASAN}

\section{Faktor penyebab dalam terjadinya kredit macet di bidang Perbankan}

Hukum Perbankan menurut pendapat Muhammad Djumhana adalah sebagai kumpulan peraturan hukum yang mengatur kegiatan lembaga keuangan bank yang meliputi segala aspek, dilihat dari segi esensi, dan eksistensinya, serta hubungannya dengan bidang kehidupan lain. ${ }^{11}$ Tingkat pertumbuhan dan perkembangan ekonomi yang stabil yang didukung oleh kondisi pasar merupakan kondisi ideal yang diharapkan oleh semua pihak, namun terkadang hal ini tidak selalu terjadi. Penurunan nilai tukar mata uang, kenaikan suku bunga pinjaman yang terus menerus, dan penurunan daya beli masyarakat (inflasi) telah sangat mempengaruhi operasi perekonomian secara keseluruhan. Keadaan ini berdampak pada menurunnya kemampuan membayar debitur bank. Ketidakmampuan debitur atau berkurangnya kemampuan membayar dengan mencicil merupakan tanda awal terjadinya kredit macet di sektor perbankan. Namun, karena faktor selain inflasi, kredit macet juga dapat terjadi. Kredit macet yang muncul harus segera ditangani oleh bank agar tidak menjadi kredit macet, jika persentase kredit macet terus meningkat maka akan berpengaruh pada kesehatan bank. Oleh karena itu, bank wajib menerapkan dan melaksanakan prinsip kehati-hatian terkait ekspansi kredit. ${ }^{12}$

Kredit bermasalah dikategorikan menjadi tiga bagian, yaitu kredit kurang lancar, kredit yang diragukan, dan kredit macet. Setiap bank sangat mengkhawatirkan reputasi buruk tersebut, karena akan merusak keadaan keuangan bank bahkan dapat menyebabkan kegiatan usaha bank terhenti. Bank yang berfungsi sebagai penyedia jasa keuangan dalam perkembangannya dapat melalui tahapan kredit bermasalah atau biasa disebut dengan kredit macet. Situasi ini dapat menghambat perkembangan Bank Dunia sebagai penyedia jasa keuangan. Kredit macet dipengaruhi oleh berbagai faktor yang sangat mempengaruhi stabilitas bank, namun pada dasarnya hanya ada dua faktor utama yang dapat menyebabkan terjadinya kredit macet pada bank, yaitu: ${ }^{13}$

\section{Faktor Internal}

1. Kurangnya pemahaman bank dalam melaksanakan analisa kemampuan atas permintaan kredit yang diajukan oleh debitur. Kurangnya pengetahuan dan pengalaman petugas bank dalam melaksanakan tugas sementara dapat disebabkan karena adanya suatu tekanan dari pihak lain untuk mengikuti permintaan kredit.

2. Kurangnya pengetahuan sistem informasi kredit, sistem pengawasan,serta sistem administrasi dalam perkreditan.

3. Petugas Bank tdalam memberikan kreditnya terhadap debitur itu sangat yakin akan kemampuan debitur dalam membayar kredit nantinya.

4. Petugas Bank tidak mempunyai informasi seputar debitur pada umumnya dalam meminjamkan kreditnya.

5. Petugas Bank tidak mengenal lebih dekat karakter dari debitur yang akan dipinjamkan kreditnya.

6. Biasanya pihak bank yang akan memberikan kreditnya kepada debitur itu masih mempunyai hubungan pertemanan atau keluarga sehingga prosesnya dipermudah tanpa melihatt tredrecord debiturnya tersebut.

7. Adanya tekenan dari dari pihak tertentu untuk memberikannya kredit.

${ }^{10}$ Soerjono Soekanto dan Sri Mamudji, Penelitian Hukum Normatif suatu Tinjauan Singkat,(Jakarta: Rajawali, 1985), hlm.

${ }^{11}$ Rani Apriani dan Hartanto. Hukum Perbankan dan Surat Berharga. (Yogyakarta,Deepublish, 2019), hlm. 1

12 Triandi, Aan, "Analisis Tentang Restrukturisasi Kredit Untuk Menghindari Terjadinya Kredit Macet (Studi Pada PT.

Bank Rakyat Indonesia (Persero) Tbk Cabang Lubuk Pakam)”, Tesis Magister Kenotariatan, (Medan, USU, 2018), hlm. 11

13 Simulasicredit.com, "Faktor Utama Yang Menyebabkan Kredit Macet" (https://www.google.co.id/amp/s/www.simulasikredit.com/amp/faktor-utama-yang-menyebabkan-kredit-macet/) Diakses pada pukul 17.24 WIB. 


\section{Faktor Eksternal}

Adapun faktor Eksternal disebabkan oleh debitur yang tidak dapat memenuhi prestasinya, faktor-faktor tersebut diantara lain:

1. Kegagalan debitur dalam melakukan kegiatan usaha

2. Turunnya kegiatan perekonomian daan naiknya suku bunga bank

3. Debitur di PHK secara sepihak ditempat kerja debiturnya.

4. Adanya itikad tidak baik dari debitur.

5. Ditemukannya pinjaman kredit tanpa sepengetahuan pihak keluarga yang dapat menyebabkan kurangnya rasa tanggung jawab debitur.

6. Penyalahgunaan kredit oleh debitur.

7. Adanya debitur debitur yang bekerja sebagai buruh, petani, nelayan sehingga keuangan mereka tidak bisa dijamin pada setiap saat, melainkan pada waktu tertentu saja. ${ }^{14}$

\section{Pelaksanaan penyelesaian kredit macet di bidang Perbankan secara Negoisasi/ Restrukturisasi}

Penyelesaian kredit macet melalui jalur non-litigasi merupakan upaya untuk mengatasi kredit macet yang sifatnya sementara karena apabila upaya ini gagal dilakukan, maka upaya terakhir yang akan ditempuh oleh kedua belah pihak adalah upaya penyelesaian melalui jalur hukum.

Berbicara mengenai kredit macet ada beberapa upaya yang bisa dilakukan oleh Bank tidak hanya dengan cara melelangkan barang jaminan, melelangkan barang jaminan merupakan upaya terakhir yang dilakukan oleh bank apabila debitur tidak sanggup lagi dalam memenuhi prestasinya. Upaya lain yang dapat dilakukan oleh bank dalam mengatasi terjadinya kredit macet salah satunya dengan melakukan penjadwalan kembali terhadap perjanjian kredit tersebut.

Pada kasus kredit macet, debitur dianggap mengingkari janji untuk membayar bunga dan/atau kredit pokok yang sudah jatuh tempo sehingga menyebabkan keterlambatan pembayaran atau sama sekali tidak melakukan pembayaran. ${ }^{15}$

Negoisasi merupakan suatu langkah penyelesaian kredit macet antara kreditur dan debitur yang dilakukan secara berunding kembali dengan memperingan syarat-syarat pengembalian kredit sehingga dengan peringanan tersebut diharapkan debitur dapat melaksanakan kembali prestasinya dalam penyelesaian kredit. Jadi tahapan penyelesaian kredit macet ini belum menggunakan bantuan lembaga hukum karena debitur disini masih memiliki itikad baik dan responsive. Itikad baik dari debitur merupakan syarat yang paling utama dalam penyelesaian kredit secara negoisasi.

Debitur juga harus siap mengikuti syarat yang telah ditentukan oleh pihak Bank, karena banyak solusi yang akan ditawarkan. Negoisasi dapat diupayakan selama debitur memiliki itikad baik dalam memberikan kembali pinjaman kreditnya. Upaya tersebut dilakukan dengan cara sebagai berikut:

\section{Rescheduling (Penjadwalan Kembali)}

Rescheduling adalah upaya pertama yang dilakukan oleh pihak bank sebagai penyelamatan yang diberikan bank kepada debitur. Langkah ini dilaksanakan jika pihak debitur tidak dapat memenuhi prestasinya dalam hal melakukan pembayaran kembali angsuran pokok ataupun bunga kredit. Rescheduling merupak penjadwalan kembali mengenai jangka waktu pembayaran sebagian atau seluruh prestasi debitur.

\section{Reconditioning (Persyaratan Kembali)}

Reconditioning adalah upaya yang dilakukan oleh pihak bank sebagai penyelamatan kredit yang diberikan dengan cara melakukan perubahan sebagian atau seluruh persyaratan yang telah disetujui bersama pihak debitur dan tertulis dalam perjanjian kredit.

\section{Restructuring (Penataan Kembali)}

Restructuring merupakan upaya penyelamatan kredit yang terpaksa harus dilakukan oleh bank dengan cara melakukan perubahan struktur pembiayaan yang melandasi pemberian kredit. ${ }^{16}$

${ }^{14}$ Sri Retno Widyorini, "Resceduling Sebuah Upaya Non-Litigasi Dalam Penyelesaian Kredit Macet”. Spektrum Hukum (2016): 131 .

15 Azies Bauw, "Penyelesaian Kredit Bermasalah Melalui Litigasi Dan Non Litigasi Pada PT. Bank Tabungan Negara (Persero) Tbk. Kantor Cabang Jayapura”, Legal Pluralism, Vol, 6 No. 2 (2016): 228.

${ }^{16}$ Ibid. hlm. 236-239 


\section{SIMPULAN}

1. Faktor penyebab terjadinya kredit macet di bidang perbankan diantaranya adanya kegagalan yang menima usaha debitur, adanya itikad tidak baik dari debitur, ditemukannya pinjaman kredit tanpa sepengetahuan pihak keluarga yang dapat menyebabkan kurangnya rasa tanggung jawab, penyalahgunaan kredit oleh debitur dan adanya debitur debitur yang bekerja sebagai buruh, petani, nelayan sehingga keuangan mereka tidak bisa dijamin pada setiap saat, melainkan pada waktu tertentu saja.

2. Proses penyelesaian kredit macet di bidang Perbankan dapat dilakukan melalui jalur litigasi dan non-litigasi. Namun tetapi, apabila debitur masih memiliki itikad baik untuk membayar hutang-hutangnya maka pihak perbankan lebih memilih untuk menggunakan jalur non-litigasi sebagai alternative penyelesaian sengketa kredit macet apabila debitur wanprestasi salah satu nya yaitu secara negoisasi yang dapat dilakukan melalui tiga cara diantaranya penjadwalan kembali (Rescheduling), persyaratan kembali (Reconditioning), dan penataan kembali (Restructuring). Negosiasi adalah proses tawar-menawar dengan jalan berunding guna mencapai kesepakatan bersama antara satu pihak (kelompok atau organisasi) dan pihak (kelompok atau organisasi) yang lain. Pada tahap penyelesaian ini debitur akan diberikan surat tagihan terlebih dahulu lalu dilanjutkan dengan surat peringatan. Setelah itu kedua belah pihak berhadapan langsung dan membicarakan lagi mengenai proses terjadinya pemenuhan prestasi pelunasan hutang sehingga menyebabkan kredit macet.

\section{DAFTAR PUSTAKA}

\section{Buku}

Apriani, Rani dan Hartanto. Hukum Perbankan dan Surat Berharga. Yogyakarta : Deepublish. 2019.

Hermansyah. Hukum Perbankan Nasional Indonesia. Jakarta : Kencana. 2005.

Nugroho, Sigit Sapto, dan Yuni Purwanti. Hukum Perbankan Mengenal Prudent Banking Principle. Klaten : Lakesisha. 2020.

P. Usanti, Trisadani, dan Abd. Shomad. Hukum Perbankan. Jakarta : PT Fajar Interpratama. 2016.

Soerjono Soekanto dan Sri Mamudji, Penelitian Hukum Normatif suatu Tinjauan Singkat, Jakarta: Rajawali, 1985

Usman, Rachmadi, Aspek-Aspek Hukum Perbankan Di Indonesia. Jakarta : PT Gramedia Pustaka Utama. 2002.

Winata, Frans Hendra. Hukum Penyelesaian Sengketa. Edisi 2. Jakarta : Kencana. 2012.

\section{Peraturan Perundang-undangan}

Undang-Undang Nomor 10 Tahun 1998 Tentang Perubahan Atas Undang-Undang Nomor 7 Tahun 1992 Tentang Perbankan.

Undang-Undang Nomor 30 Tahun 1999 Tentang Arbitrase dan Alternatif Penyelesaian Sengket

\section{Jurnal/Skripsi}

Amir, Ana Afriana. "Penyelesaian Kredit Macet Melalui Jalur Non-Litigasi Pada PT. Bank Pembangunan Daerah Sulawesi Selatan dan Barat", Tesis Magister Ilmu Hukum, (Makassar, Unhas, 2020).

Bauw, Aziz "Penyelesaian Kredit Bermasalah Melalui Litigasi Dan Non Litigasi Pada PT. Bank Tabungan Negara (Persero) Tbk. Kantor Cabang Jayapura", Legal Pluralism, Vol, 6 No. 2 (2016).

Kaddhani, Muhammad. "Penyelesaian Kredit Bermasalah Melalui Jalur Non-Litigasi Pada PT. Bank Rakyat Indonesia (Persero) Tbk Cabang Sinjai”, Skripsi Ilmu Hukum, Program Sarjana Ilmu Hukum, (Makassar: Universitas Alauddin Makassar, 2018).

Thriyana, Djuyanto. "Penyelesaian Kredit Bermasalah Dalam Praktek Perbankan Di Indonesia". Dialogia Iuridica. Vol, 11 No. 2 (2020).

Triandi, Aan, "Analisis Tentang Restrukturisasi Kredit Untuk Menghindari Terjadinya Kredit Macet (Studi Pada PT. Bank Rakyat Indonesia (Persero) Tbk Cabang Lubuk Pakam)”, Tesis Magister Kenotariatan, (Medan, USU, 2018),

Widyorini, Sri Retno. "Resceduling Sebuah Upaya Non-Litigasi Dalam Penyelesaian Kredit Macet”. Spektrum Hukum (2016).

\section{Internet}

Simulasicredit.com. "Faktor Utama Yang Menyebabkan Kredit Macet". https://www.google.co.id/amp/s/www.simulasikredit.com/amp/faktor-utama-yang-menyebabkan-kredit-macet/ (Diakses pada tanggal 19 April 2021 pukul 17.24 WIB) 